\title{
Makalah Audit Sistem Informasi Berbasis Komputer
}

\author{
Email : gillanfatahillah.student@umitra.ac.id
}

\begin{abstract}
1.1 ABSTRAK
Pengendalian (controlling) merupakan salah satu fungsi manajemen dalam mencapaitujuan organisasi,yang merupakan manifestasidari usaha manajemen untuk mengurangiresiko kerugian dan penyimpangan dalamsuatu organisasi.Pengendalian Internal yangefektif merupakan salah satu faktor kuncidalam kesuksesan sebuah organisasi.Dalampengendalian intern yang efektif, manajemen dan segenap anggota organisasi yang lainakan memiliki tingkat keyakinan yangmemadai dalam mencapai tujuan dan sasaran suatu organisasi.Dimana dengan adany sistem pengendalian intern yang efektif,dapat membantu dalam mencapai tujuan organisasi yang antara lain dalam hal efisiensi,mengurangi resiko kerugian,dan menghasilkan suatu laporan keuangan yang andal dan sesuai dengan hukum dan peraturan yang berlaku.

Dengan semakin dominannya penggunaan komputer dalam membantu kegiatan operasional diberbagai perusahaan,mak diperlukan standar-standar yang tepat sebagai alat pengendali internal untuk menjamin bahwa data elektronik yangdiproses adalah benar.Sehingga data elektronik tersebut menghasilkan pelaporan keuangan perusahaan yang dapat dipertanggungjawabkan.
\end{abstract}




\section{LANDASAN TEORI}

\subsection{Definisi Audit Sistem Informasi}

Merupakan suatu proses pengumpulan dan pengevaluasian bukti-bukti yang dilakukan oleh pihak yang independen dan kompeten untuk mengetahui apakah suatu sistem informasi dan sumber daya terkait, secara memadai telah dapat digunakan untuk:

melindungi aset

menjaga integritas dan ketersediaan sistem dan data

menyediakan informasi yang relevan dan handal

mencapai tujuan organisasi dengan efektif menggunakan sumber daya dengan efisien,

\subsection{Tujuan Dan Lingkup Audit Sistem Informasi}

Tujuan Audit Sistem Informasi dapat dikelompokkan ke dalam dua aspek utama, yaitu:

1. Conformance (Kesesuaian) - Pada kelompok tujuan ini audit sistem informasi difokuskan untuk memperoleh kesimpulan atas aspek kesesuaian, yaitu : Confidentiality (Kerahasiaan), Integrity (Integritas), Availability (Ketersediaan) dan Compliance (Kepatuhan).

2. Performance (Kinerja) - Pada kelompok tujuan ini audit sistem informasi difokuskan untuk memperoleh kesimpulan atas aspek kinerja, yaitu : Effectiveness (Efektifitas), Efficiency (Efisiensi), Reliability (Kehandalan).

\subsection{PERAN AUDITOR dan AKUNTAN}

Sebagian besar jurusan akuntansi mengisi posisi internal maupun eksternal auditor dan akan sangat dilibatkan dalam program dan proses audit.

Pemakaian auditor terus meningkat sebagai penasehat selama merancang pengembangan sistem. Auditor mungkin membantu dalam pemilihan ukuran keamanan dan kendali, menaksir cost, dan pengendalian keuntungan dan penentuan prosedur audit yang paling efektif.

\section{PEMBAHASAN}

\subsection{TIPE AUDIT}

Audit yang dilaksanakan sesuai tipe perusahaan yaitu operasional, compliance, pengembangan system, internal control, financial dan kecurangan audit. Empat jenis auditor yang dilibatkan dalam menyelenggarakan audit yang di list adalah:

a. Internal auditor adalah karyawan perusahaan,yang pada umumnya melaksanakan compliance,operasional,pengembangansiste $\mathrm{m}$,pengawasan intern\&kecurangan audit.

b. Ekstenal auditor adalah akuntan publik independen yang ditugaskan oleh perusahaan, secara khusus melaksanakan audit keuangan. Dalam berbagai macam audit keuangan, eksternal auditor dibantu oleh internal auditor. akantetapi auditor eksternal yang bertanggung jawab untuk menegaskan kewajaran laporan keuangan.

c. Goverment auditor,melaksanakan pemenuhan audit/menguji laporan perusahaan atas pengawasan yang menyangkut para pegawai pemerintahan.contoh: pemeriksa bank pemerintahan melaksanakan audit bank,auditor yang dtugaskan oleh auditor negara yang umumnya melaksanakan audit daerah dan para pegawai pemerintah.

d. Fraud auditor, mengkhususkan dalam menyelidiki kecurangan\&bekerja secara tertutup dengan internal auditor\&pengacara,fraud examminer contoh: kesatuan FBI penyelidikan kecurangan,perusahan besar akuntan publik,IRS, perusahaan asuransi.

\section{$3.2 \quad$ JENIS-JENIS AUDIT}


a. Operational audit, terkonsen pada efisiensi dan efectifitas sumberdaya digunakan untuk melaksanakan tugas, meliputi kesesuaian praktik\&prosedur dengan peraturan.

b. Compliance audit terkonsentrasi pada cakupan undang-undang, peraturan pemerintah, pengendalian dan kewajiban badan eksternal lain yang telah diikut.

c. Project manajement\&change control audit,(dulu dikenal sebagai suatu pengembangan sistem audit)terkonsentrasi oleh efesiensi\&efektifitas pada berbagai tahap pengembangan sistem siklus kehidupan yang sedang diselenggarakan.

d. Internal control audit terkonsentrasi pada evaluasi struktur pengendalian internal.

e. Financial audit terkonsentrasi pada kewajaran laporan keuangan yang menunjukan posisi keuangan, aliran kas dan hasil kinerja perusahaan.

f. Fraud audit adalah nonrecurring audit yang dilaksanakan untuk mengumpulkan bukti untuk menentukan apakah sedang terjadi, telah terjadi atau akan terjadi kecurangan. Dan penyelesaian hal sesuai dengan pemberian tanggung jawab.

\subsection{Audit sistem informasi berbasis komputer}

Istilah system informasi menyiratkan penggunaan teknologi komputer dalam suatu organisasi untuk menyediakan informasi bagi pengguna. Sistem informasi berbasiskomputer merupakansatu rangkaian perangkat lunak dan perangkat lunak yang dirancang untuk mentransformasi data menjadi informasi yang berguna.

Sistem Informasi audit adalah sebagai berikut:

1. Sistem Pengolahan Data Elektronik (EDP)

2. Sistem Pemrosesan Data (DP)

3. Sistem Informasi Manajemen (SIM)

4. Sistem Pendukung Keputusan (DSS)

5. Sistem Pakar (ES)

6. Sstem Informasi Eksekutif (EIS)

7. Sistem Informasi Akuntansi (SIA)
8. Sistem Pendukung Keputusan (DSS)

9. Sistem Pakar (ES)

10. Sistem Informasi Eksekutif (EIS)

11. Sistem Informasi Akuntansi (SIA)

\section{Pemrosesan Data Elektronik}

Pemrosesan data elektronik (EDP) merupakan penggunaan teknologi komputer untuk menjalankan pemrosesan data transaksi suatu organisasi.EDP merupakan satu aplikasi system informasi yang fundamental di setiap organisasi. Seiring perkembangan teknologi komputer,yang makinbanyak dikenal oleh masyarakat,istilah pemrosesan data (DP) memiliki pengertian yang sama dengan EDP.

\section{Sistem informasi manajemen (SIM)}

Sistem informasi manajemen menyediakan beragam informasi yang lebih luas dibandingkan dengan informasi yang dihasilkan oleh EDP. Sistem informasi manajemen mengakui bahwa manajer dalam suatu organisasi menggunakan dan membutuhkan informasi untuk mengambil keputusan dan bahwa system informasi dapat membantu menyediakan informasi tersebut bagi manajer.

\section{Subsistem SIM Fungsional}

Banyak organisasi menrapkan konsep SIM ke dalam area fungsional dalam organisasi. Istilah seperti system informasi pemasaran,system informasi manufaktur,serta system informasi sumber daya manusia mengindikasikan kaitan konsep SIM dengan pengembangan system informasi yang spesifik untuk mendukung pengambilan keputusan dalam subunit organisasi.

\section{Sistem informasi pemasaran}

Merupakan suatu SIM yang memberikan informasi bagi departemen pemasaran.Banyak dari informasi yang disajikan berasal dari system informasi 
akuntansi,misalnya ringkasan penjualan dan informasi biaya. Informasi lain mesti dikumpulkan dari lingkungan organisasi misalnya data preferensi konsumen,profil konsumen,dan informasi produk pesaing.

\section{Sistem informasi pemanukfakturan} Merupakan SIM yang menyediakan informasi untuk digunakan oleh fungsi produksi. Banyak dari informasi yang disajikan berasal dari system informasi akuntansi.Contohnya adalah ringkasan persediaan dan informasi biaya.Informasi yang lain mesti dikumpulkan dari lingkungan organisasi,sebagai contoh data bahan baku,profil pemasok potensial,dan informasi mengenai teknik produksi yang baru.

\subsection{Manfaat Audit}

Adapun manfaat audit sistem informasi berbasis komputer antara lain adalah:

\section{a. Kerugian akibat kehilangan data}

Data yang diolah menjadi sebuah informasi, merupakan aset penting dalam organisasi bisnis saat ini. Banyak aktivitas operasi mengandalkan beberapa informasi yang penting. Informasi sebuah organisasi bisnis akan menjadi sebuah potret atau gambaran dari kondisi organisasi tersebut di masa lalu, kini dan masa mendatang. Jika informasi ini hilang akan berakibat cukup fatal bagi organisasi dalam menjalankan aktivitasnya.

Sebagai contoh adalah jika data nasabah sebuah bank hilang akibat rusak, maka informasi yang terkait akan hilang, misalkan siapa saja nasabah yang mempunyai tagihan pembayaran kredit yang telah jatuh tempo. Atau juga misalkan kapan bank harus mempersiapkan pembayaran simpanan deposito nasabah yang akan jatuh tempo beserta jumlahnya. Sehingga organisasi bisnis seperti bank akan benar-benar memperhatikan bagaimana menjaga keamanan datanya. Kehilangan data juga dapat terjadi karena tiadanya pengendalian yang memadai, seperti tidak adanya prosedur back-up file. Kehilangan data dapat disebabkan karena gangguan sistem operasi pemrosesan data, sabotase/gangguan karena alam seperti gempa bumi, kebakaran/banjir.

\section{b. Kerugian akibat kesalahan pemrosesan komputer}

Pemrosesan komputer menjadi pusat perhatian utama dalam sebuah sistem informasi berbasis komputer. Banyak organisasi telah menggunakan komputer sebagai sarana untuk meningkatkan kualitas pekerjaan mereka. Mulai dari pekerjaan yang sederhana, seperti perhitungan bunga berbunga sampai penggunaan komputer sebagai bantuan dalam navigasi pesawat terbang atau peluru kendali. Dan banyak pula di antara organisasi tersebut sudah saling terhubung dan terintegrasi. Akan sangat mengkhawatirkan bila terjadi kesalahan dalam pemrosesan di dalam komputer. Kerugian mulai dari tidak dipercayainya perhitungan matematis sampai kepada ketergantungan kehidupan manusia.

\section{c. Pengambilan keputusan yang salah akibat informasi yang salah}

Kualitas sebuah keputusan sangat tergantung kepada kualitas informasi yang disajikan untuk pengambilan keputusan tersebut. Tingkat akurasi dan pentingnya sebuah data atau informasi tergantung kepada jenis keputusan yang akan diambil. Jika top manajer akan mengambil keputusan yang bersifat strategik, mungkin akan dapat ditoleransi berkaitan dengan sifat keputusan yang berjangka panjang. Tetapi kadangkala informasi yang menyesatkan akan berdampak kepada pengambilan keputusan yang menyesatkan pula. 


\section{d. Kerugian karena penyalahgunaan komputer (Computer Abused)}

Tema utama yang mendorong perkembangan dalam audit sistem informasi dalam sebuah organisasi bisnis adalah karena sering terjadinya kejahatan penyalahgunaan komputer. Beberapa jenis tindak kejahatan dan penyalah-gunaan komputer antara lain adalah virus, hacking, akses langsung yang tak legal (misalnya masuk ke ruang komputer tanpa ijin atau menggunakan sebuah terminal komputer dan dapat berakibat kerusakan fisik atau mengambil data atau program komputer tanpa ijin) dan atau penyalahgunaan akses untuk kepentingan pribadi (seseorang yang mempunyai kewenangan menggunakan komputer tetapi untuk tujuan-tujuan yang tidak semestinya).

Hacking - seseorang yang dengan tanpa ijin mengakses sistem komputer sehingga dapat melihat, memodifikasi/ menghapus program komputer/ data/ mengacaukan sistem.

Virus - virus adalah sebuah program komputer yang menempelkan diri dan menjalankan sendiri sebuah program komputer atau sistem komputer di sebuah disket, data atau program yang bertujuan mengganggu atau merusak jalannya sebuah program atau data komputer yang ada di dalamnya. Virus dirancang dengan dua tujuan, yaitu pertama mereplikasi dirinya sendiri secara aktif dan kedua mengganggu atau merusak sistem operasi, program atau data.

Dampak dari kejahatan dan penyalahgunaan komputer tersebut antara lain:

Hardware, software, data, fasilitas, dokumentasi dan pendukung lainnya rusak atau hilang dicuri atau dimodifikasi dan disalahgunakan.

Kerahasiaan data atau informasi penting dari orang atau organisasi rusak atau hilang dicuri atau dimodifikasi.

Aktivitas operasional rutin akan terganggu.
Kejahatan dan penyalahgunaan komputer dari waktu ke waktu semakin meningkat, dan hampir $80 \%$ pelaku kejahatan komputer adalah orang dalam.

e. Nilai hardware, software dan personil sistem informasi.

Dalam sebuah sistem informasi, hardware, software, data dan personil adalah merupakan sumberdaya organisasi. Beberapa organisasi bisnis mengeluarkan dana yang cukup besar untuk investasi dalam penyusunan sebuah sistem informasi, termasuk dalam pengembangan sumberdaya manusianya. Sehingga diperlukan sebuah pengendalian untuk menjaga investasi di bidang ini.

\section{f. Pemeliharaan kerahasiaan informasi \\ Informasi sebuah organisasi bisnis sangat beragam,mulai data karyawan, pelanggan,transaksi\&lainya adalah amat riskan bila tidak dijaga.Seseorang dapat saja memanfaatkan informasi untuk disalahgunakan.Sebagai contoh data pelanggan rahasia,dapat digunakan oleh pesaing untuk memperoleh manfaat dalam persaingan.}

Pada saat komputer pertama kali digunakan, banyak auditor mempunyai pemikiran bahwa proses audit akan harus banyak mengalami perubahan untuk menyesuaikan dengan penggunaan teknologi komputer. Ada dua utama yang harus diperhatikan dalam audit atas pemrosesan data elektronik, yaitu pengumpulan bukti (evidence collection) dan evaluasi bukti (evidence evaluation)

\section{PENUTUP}

\subsection{Kesimpulan}


Audit Sistem Informasi Merupakan suatu proses pengumpulan\&pengevaluasian buktibukti yang dilakukan oleh pihak yang independen\&kompeten untuk mengetahui apakah suatu sistem informasi dan sumber daya terkait, secara memadai telah dapat digunakan untuk:melindungi aset,menjaga integritas\&ketersediaan

sistem\&data,menyediakan informasi yang relevan\&handal,mencapai tujuan organisasi dengan efektif,menggunakan sumber daya dengan efisien,System informasi menyiratkan penggunaan teknologi komputer dalam suatu organisasi untuk menyediakan informasi bagi pengguna.Sistem informasi berbasiskomputer merupakansatu rangkaian perangkat lunak\&perangkat lunak yang dirancang untuk mentransformasi data menjadi informasi yang berguna,secara memadai dapat digunakan untuk:

melindungi aset

menjaga integritas dan ketersediaan sistem dan data

menyediakan informasi yang relevan dan handal

mencapai tujuan organisasi dengan efektif menggunakan sumber daya dengan efisien, Tipe Audit

1. Internal auditor.

2. Ekstenal auditor.

3. Goverment auditor.

4. Fraud auditor. Jenis-jenis Audit

1. Operational audit.

2. Compliance audit terkonsentrasi pada cakupan undang-undang pemerintah.

3. Project manajement\&change control audit.

4. Internal control audit terkonsentrasi pada evaluasi struktur pengendalian internal.

5. Financial audit terkonsentrasi.

6. Fraud audit.

Audit sistem informasi berbasis komputer, Istilah sistem informasi menyiratkan penggunaan teknologi komputer dalam suatu organisasi untuk menyediakan informasi.

Sistem Informasi audit adalah sebagai berikut:

1. Sistem Pengolahan Data Elektronik (EDP)

2. Sistem Pemrosesan Data

(DP)

3. Sistem Informasi Manajemen

(SIM)

4. Sistem Pendukung Keputusan (DSS)

5. Sistem Pakar (ES)

6. Sistem Informasi Eksekutif (EIS)

7. Sistem Informasi Akuntansi (SIA)

8. Sistem Pendukung Keputusan (DSS)

REFRENSI

http://wikipedia/wiki/audit sistem informasi/org

http://definisi audit sistem informasi/wahyu hidayat.blogspot.com

http://Audit Pemerintahan dan Komputer Audit/Sri Wiwik Anggiyani/Academia.edu

http:// Audit sistem informasi berbasis komputer/agus maulana syafei/semarang/2000

\section{A. REFERENCE}

[1] 
Bandar Lampung," J. Inform., vol. 13, no. 1, pp. 90-98, 2014.

[2] A. S. Putra, "Paperplain: Execution Fundamental Create Application With Borland Delphi 7.0 University Of Mitra Indonesia," 2018.

[3] A. S. Putra, "2018 Artikel Struktur Data, Audit Dan Jaringan Komputer," 2018.

[4] A. S. Putra, "ALIAS MANAGER USED IN DATABASE DESKTOP STUDI CASE DB DEMOS."

[5] A. S. Putra, "COMPREHENSIVE SET OF PROFESSIONAL FOR DISTRIBUTE COMPUTING."

[6] A. S. Putra, "DATA ORIENTED RECOGNITION IN BORLAND DELPHI 7.0."

[7] A. S. Putra, "EMBARCADERO DELPHI XE 2 IN GPU-POWERED FIREMONKEY APPLICATION."

[8] A. S. Putra, "HAK ATAS KEKAYAAN INTELEKTUAL DALAM DUNIA TEKNOLOGY BERBASIS REVOLUSI INDUSTRI 4.0."

[9] A. S. Putra, "IMPLEMENTASI PERATURAN PERUNDANGAN UU. NO 31 TAHUN 2000 TENTANG DESAIN INDUSTRI BERBASIS INFORMATION TECHNOLOGY."

[10] A. S. Putra, "IMPLEMENTATION OF PARADOX DBASE."

[11] A. S. Putra, "IMPLEMENTATION OF TRADE SECRET CASE STUDY SAMSUNG MOBILE PHONE."

[12] A. S. Putra, "IMPLEMENTATION PATENT FOR APPLICATION WEB BASED CASE
STUDI WWW. PUBLIKLAMPUNG. COM."

[13] A. S. Putra, "IMPLEMENTATION SYSTEM FIRST TO INVENT IN DIGITALLY INDUSTRY."

[14] A. S. Putra, "MANUAL REPORT \& INTEGRATED DEVELOPMENT ENVIRONMENT BORLAND DELPHI 7.0."

[15] A. S. Putra, "PATENT AS RELEVAN SUPPORT RESEARCH."

[16] A. S. Putra, "PATENT FOR RESEARCH STUDY CASE OF APPLE. Inc."

[17] A. S. Putra, "PATENT PROTECTION FOR APPLICATION INVENT."

[18] A. S. Putra, "QUICK REPORT IN PROPERTY PROGRAMMING."

[19] A. S. Putra, "REVIEW CIRCUIT LAYOUT COMPONENT REQUIREMENT ON ASUS NOTEBOOK."

[20] A. S. Putra, "REVIEW TRADEMARK PATENT FOR INDUSTRIAL TECHNOLOGY BASED 4.0."

[21] A. S. Putra, "TOOLBAR COMPONENT PALLETTE IN OBJECT ORIENTED PROGRAMMING."

[22] A. S. Putra, "WORKING DIRECTORY SET FOR PARADOX 7."

[23] A. S. Putra, "ZQUERY CONNECTION IMPLEMENTED PROGRAMMING STUDI CASE PT. BANK BCA Tbk."

[24] A. S. Putra, D. R. Aryanti, and I. Hartati, "Metode SAW (Simple Additive Weighting) sebagai Sistem Pendukung Keputusan Guru Berprestasi (Studi Kasus: SMK Global Surya)," in Prosiding 
Seminar Nasional Darmajaya, 2018, vol. 1, no. 1, pp. 85-97.

[25] A. S. Putra and O. M. Febriani, "Knowledge Management Online Application in PDAM Lampung Province," in Prosiding International conference on Information Technology and Business (ICITB), 2018, pp. 181-187.

[26] A. S. Putra, O. M. Febriani, and B. Bachry, "Implementasi Genetic Fuzzy System Untuk Mengidentifikasi Hasil Curian Kendaraan Bermotor Di Polda Lampung," SIMADA (Jurnal Sist. Inf. dan Manaj. Basis Data), vol. 1, no. 1, pp. 2130, 2018

[27] A. S. Putra, H. Sukri, and K. Zuhri, "Sistem Monitoring Realtime Jaringan Irigasi Desa (JIDES) Dengan Konsep Jaringan Sensor Nirkabel," IJEIS (Indonesian J. Electron. Instrum. Syst., vol. 8, no. 2, pp. 221-232.

[28] D. P. Sari, O. M. Febriani, and A. S. Putra, "Perancangan Sistem Informasi SDM Berprestasi pada SD Global Surya," in Prosiding Seminar Nasional Darmajaya, 2018, vol. 1, no. 1, pp. 289-294. 